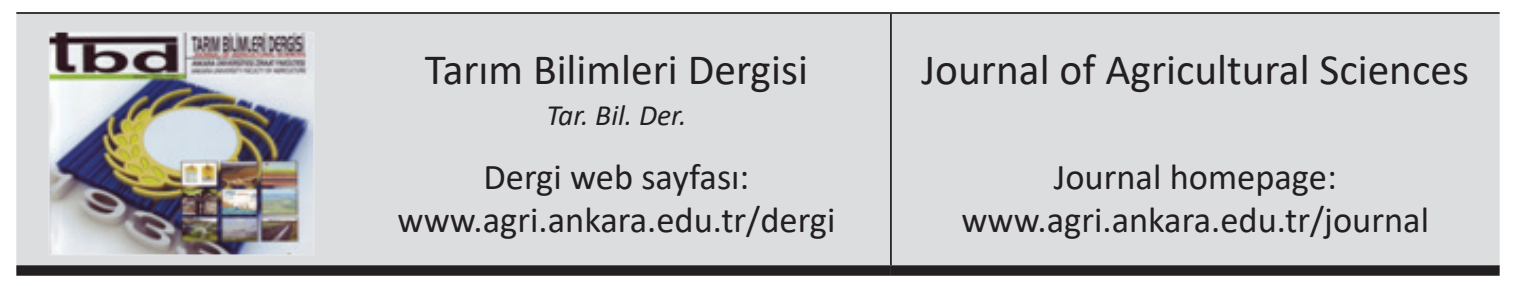

\title{
Effects of Olive Leaf (Oleuropein) Supplementation on Quality of Breast Meat in Broilers
}

\author{
İsmail YAVAŞ ${ }^{\mathrm{a}}$, Hatice BASMACIOĞLU MALAYOĞLU ${ }^{\mathrm{b}}$ \\ 'Ankara University, Faculty of Agriculture, Department of Animal Science, Dışkapı, ANKARA

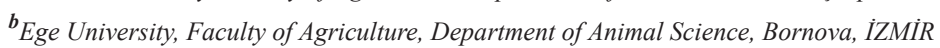

\section{ARTICLE INFO}

Research Article

Corresponding Author: İsmail YAVAȘ, E-mail: iyavas@ankara.edu.tr, Tel: +90 (312) 5961415

Received: 23 May 2018, Received in Revised Form: 04 August 2018, Accepted: 03 October 2018

\begin{abstract}
In this study, we investigated the effect of dietary olive leaf (oleuropein) supplementation at different levels on breast meat color and $\mathrm{pH}_{24}$ in along with TBA values of breast meats which were stored at $+4{ }^{\circ} \mathrm{C}$ during the 11-day in broilers. For this purpose 320 one-day-old Ross-308 chicks randomly assigned to four groups ( 5 replicates per group, 16 chicks per replicates). In trial, dietary treatments consist of corn-soybean meal diet without or with 125,250 and $500 \mathrm{mg}$ $\mathrm{kg}^{-1}$ oleuropein supplementation respectively. At the end of trial, two chicks per replicate were slaughtered and meat samples were collected for lipid oxidation, color and $\mathrm{pH}_{24}$ measurement. According to the obtained findings, $250 \mathrm{mg}$ $\mathrm{kg}^{-1}$ oleuropein supplementation on broiler diets significantly $(\mathrm{P}<0.05)$ decreased TBA values $\left(\mathrm{mg} \mathrm{MDA} \mathrm{kg}{ }^{-1} \mathrm{meat}\right)$ of breast meats compared with other groups. TBA values of breast meats significantly $(\mathrm{P}<0.05)$ increased during storage time. While breast meat brightness $\left(\mathrm{L}^{*}\right)$ and yellowness $\left(\mathrm{b}^{*}\right)$ values and $\mathrm{pH}_{24}$ were not significantly $(\mathrm{P}>0.05)$ affected by oleuropein supplementation at different levels, redness $\left(\mathrm{a}^{*}\right)$ value significantly $(\mathrm{P}<0.05)$ increased compared with control group. As a result of the study, it is possible to say that oleuropein demonstrated antioxidant activity linked with supplementation level and it can be used at level of $250 \mathrm{mg} \mathrm{kg}^{-1}$ as phytobiotic antioxidant in broiler diets.

Keywords: Olive leaf; Oleuropein; Broiler; Antioxidant; Lipid oxidation
\end{abstract}

(C) Ankara Üniversitesi Ziraat Fakültesi

\section{Introduction}

Lipid oxidation and microbial growth are major problems during the storage of chicken meat. Therefore, the use of antimicrobial and antioxidants in broiler is quite common. Nowadays, the use of natural antioxidants instead of synthetic antioxidants (butyl hydroxyanisole, butyl hydroxy toluene, tertiary butyl hydroxyquinonone and propyl gallates) are on the agenda because of consumers' demand for safety food and natural feed additives
(Botsoglou et al 2010a). In this demand, the use of vitamins such as $\mathrm{E}$ or $\mathrm{C}$ vitamins and some phytobiotics as natural antioxidants are emphasized. Phytobiotics can be defined as extracts or essential oils from various parts of plants. The use of some plants and spices such as carnations, rosemary, sage, green tea, thyme and olive leaf, which are antioxidant, in broiler chickens has been discussed in recent years. These products can be used either directly or processed extract form or essential oil form on broiler feed (Loetscher et al 2013). 
Olive and olive oil production are important and traditional agro-industrial activity in the Mediterranean countries since the ancient times and almost all of the world's olive production and consumption is carried out in Mediterranean countries (Basmacioğlu-Malayoğlu \& Aktaş 2011). It is reported that olive leaf, olive oil processing by products, contains more than 30 phenolic compounds which are generally classified as phenolic acids, phenolic alcohols, flavonoids, secoiridoid and lignans. One of these, oleuropein is the major bioactive compound and may reach concentrations of $90 \mathrm{~g} \mathrm{~kg}^{-1}$ in dried olive leaves (Benavente-Garcia et al 2000). Antimicrobial and antioxidant effects of this compound have been demonstrated with some studies (Bisignano et al 1999; Markin et al 2003; Lee \& Lee 2010).

In this study, we aimed the investigate effects of oleuropein supplementation at different levels on meat quality and TBA values of breast meat during the storage time in broilers.

\section{Material and Methods}

\subsection{Animals and experimental treatments}

In this trial, 320 one-day-old Ross 308 chicks were randomly assigned to 4 groups (5 replicates/group, 16 chicks/replicates). At the beginning of study chicks were weighed, wing banded and distributed into 20 floors. Each $1.2 \times 1.1 \mathrm{~m}^{2}$ floor pen was furnished with wood shavings litter, a round feeder and a round drinker. Water and feed were offered ad libitum. Temperature and relative humidity was maintained within the optimum range. Lighting was $23 \mathrm{~h} \mathrm{light}$ and one hour darkness. The trial lasted for 6 weeks. The basal diet formulated in granule form for starter (1-10 days of age) and pellet forms for grower (11-24 days of age) and finisher (25-42 days of age) periods. The ingredients and composition of basal diets used at different ages is shown in Table 1. The experimental groups consisted of control group fed the basal diet (no oleuropein supplementation) and three groups fed the basal diet supplemented with oleuropein at levels of 125 (OLE125), 250 (OLE250) and 500 (OLE500) $\mathrm{mg} \mathrm{kg}^{-1}$ of diet, respectively. For this purpose firstly oleuropein content of olive leaf was analyzed. Olive leaf's chemical composition, oleuropein and total phenol contents is shown in Table 2. Then olive leaf was mixed at different levels to soybean meal used in ration and then mixture was added to the compound feed to provided oleuropein levels. The oleuropein contents of diets supplemented with olive leaf were as follows: $125 \mathrm{mg} \mathrm{kg}^{-1}, 250 \mathrm{mg} \mathrm{kg}^{-1}$ and $500 \mathrm{mg}$ $\mathrm{kg}^{-1}$ respectively. Dried olive leaf used in trial was obtained from a commercial company operating in the Edremit/Turkey.

\subsection{Determination of breast meat quality}

At the end of the trial, 40 broilers ( 10 chicks in each group) were randomly sampled for determination of breast meat quality. After slaughter carcasses were trimmed for breast meat by removing skin, bones and connective tissue. Following trimming, breast meat from each chick was separated into two sections. Right section was used for lipid oxidation, the other for color and $\mathrm{pH}_{24}$ measurements. Samples were placed on the plastic plates and covered with polyethylene film and stored in the refrigerator at +4 ${ }^{\circ} \mathrm{C}$ for lipid oxidation measurement. Thiobarbituric acid value (TBA) was determined on days 1,5 and 11 as malondialdehyde (MDA) equivalence during 11 days storage. In order to determine the TBA value (mg MDA $\mathrm{kg}^{-1}$ ), $5 \mathrm{~g}$ sample was blended for 2 minute in a homogenizer (AM-7, Nissei Co., Tokyo, Japan) with extracting solution (50 mL 2 M phosphoric acid) which containing 20 percent trichloroacetic acid in. The resulting slurry was diluted to $100 \mathrm{~mL}$ with distilled water and homogenized and filtered (Whatman No. 1 filter paper). $5 \mathrm{~mL}$ of filtrate was homogenized $(5 \mathrm{~mL}$ of 2-thiobarbituric acid) and reserved in the dark for $15 \mathrm{~h}$ at room temperature. The resulting color was measured with spectrophotometer at $530 \mathrm{~nm}$ (Witte et al 1970). For color ( $\mathrm{L}^{*}$ - lightness, $\mathrm{a}^{*}$ - redness and $\mathrm{b}^{*}$ - yellowness) and $\mathrm{pH}$ at $\mathrm{pH}_{24}$ measurement breast meat samples were stored at $4{ }^{\circ} \mathrm{C}$ for 24 hours after slaughter. Objective measurement of color was performed at the surface of breast meat using a Minolta CR-300 colorimeter to measure CIE 
Table 1- Ingredients and nutrients composition of the basal diets

\begin{tabular}{|c|c|c|c|}
\hline & $\begin{array}{r}\text { Starter } \\
(0-10 \text { days })\end{array}$ & $\begin{array}{r}\text { Grower } \\
\text { (11-24 days) }\end{array}$ & $\begin{array}{r}\text { Finisher } \\
(25-42 \text { days })\end{array}$ \\
\hline \multicolumn{4}{|l|}{ Ingredients $\left(\mathrm{g} \mathrm{kg}^{-1}\right)$} \\
\hline Corn & 263.60 & 276.00 & 224.80 \\
\hline Soybean meal & 351.90 & 305.80 & 185.00 \\
\hline Wheat & 150.00 & 160.00 & 200.00 \\
\hline Full fat soybean & 64.40 & 47.30 & 120.00 \\
\hline Wheat bran & 60.00 & 80.00 & 140.00 \\
\hline Sunflower meal & 20.00 & 30.00 & 50.00 \\
\hline Soybean oil & 49.80 & 65.00 & 47.70 \\
\hline Dicalcium phosphate & 15.50 & 12.50 & 10.40 \\
\hline Limestone & 10.00 & 9.50 & 9.50 \\
\hline Common salt & 3.50 & 2.90 & 2.90 \\
\hline DL-Methionine & 3.40 & 2.80 & 3.10 \\
\hline L-Lysine & 3.00 & 3.00 & 2.50 \\
\hline L-Threonine & 0.70 & 0.50 & 0.50 \\
\hline Sodium bicarbonate & 1.10 & 1.60 & 1.10 \\
\hline Premix $^{1,2,3,4}$ & 1.00 & 1.00 & 1.00 \\
\hline Enzyme+Phytase & 1.00 & 1.00 & 1.00 \\
\hline Anticoccidials & 0.60 & 0.60 & - \\
\hline Choline chloride & 0.50 & 0.50 & 0.50 \\
\hline \multicolumn{4}{|l|}{ Analyzed values $\left(\mathrm{g} \mathrm{kg}^{-1}\right)$} \\
\hline Dry matter & 893.50 & 895.40 & 896.30 \\
\hline Crude protein & 231.07 & 210.40 & 190.60 \\
\hline Ether Extract & 71.50 & 92.10 & 8.40 \\
\hline Crude ash & 62.55 & 50.30 & 50.40 \\
\hline Crude fiber & 34.00 & 33.70 & 38.20 \\
\hline Calcium & 10.20 & 9.10 & 8.40 \\
\hline Total phosphorus & 7.37 & 6.80 & 7.20 \\
\hline Starch & 348.42 & 372.50 & 393.70 \\
\hline Sugar & 46.47 & 41.50 & 40.80 \\
\hline Metabolizable energy*, Kcal kg ${ }^{-1}$ & 3025.00 & 3150.00 & 3200.00 \\
\hline
\end{tabular}

${ }^{1}$, vitamin premix per $\mathrm{kg}$ of starter diet; $11000 \mathrm{IU}$ vitamin $\mathrm{A} ; 5000 \mathrm{IU}$ vitamin $\mathrm{D}_{3} ; 75 \mathrm{IU}$ vitamin $\mathrm{E} ; 3 \mathrm{mg}$ vitamin $\mathrm{K} ; 3 \mathrm{mg}$ vitamin $\mathrm{B}_{1} ; 8 \mathrm{mg}$ vitamin $\mathrm{B}_{2} ; 60 \mathrm{mg}$ niacin; $15 \mathrm{mg}$ Pantothenic acid; $0.15 \mathrm{mg}$ biotin; $2 \mathrm{mg}$ folic acid; $0.16 \mathrm{mg}$ Vit $\mathrm{B}_{12}{ }^{2}$ vitamin premix per kg of grower diet: 9000 IU vitamin $\mathrm{A} ; 5000 \mathrm{IU}$ vitamin $\mathrm{D}_{3} ; 50 \mathrm{IU}$ vitamin $\mathrm{E} ; 3 \mathrm{mg}$ vitamin $\mathrm{K} ; 2 \mathrm{mg}$ vitamin $\mathrm{B}_{1} ; 6 \mathrm{mg}$ vitamin $\mathrm{B}_{2} ; 60 \mathrm{mg}$ niacin; $15 \mathrm{mg}$ Pantothenic acid; $0.10 \mathrm{mg}$ biotin; $1.75 \mathrm{mg}$ folic acid; $0.16 \mathrm{mg}$ Vit $\mathrm{B}_{12}{ }^{3}$ Vitamin premix per kg of finisher diet: $9000 \mathrm{IU}$ vitamin $\mathrm{A} ; 4000 \mathrm{IU}$ vitamin $\mathrm{D}_{3} ; 50$ IU vitamin E; 2 mg vitamin $\mathrm{K} ; 2 \mathrm{mg}$ vitamin $\mathrm{B}_{1} ; 5 \mathrm{mg}$ vitamin $\mathrm{B}_{2} ; 40 \mathrm{mg}$ niacin; $15 \mathrm{mg}$ Pantothenic acid; 0,10 mg biotin; $1.50 \mathrm{mg}$ folic acid; $0.10 \mathrm{mg} \mathrm{Vit} \mathrm{B}_{12}{ }^{4}$ Mineral premix per kg of diet: $100 \mathrm{mg} \mathrm{Zn;} 120 \mathrm{mg} \mathrm{Mn} ; 40 \mathrm{mg} \mathrm{Fe} ; 16 \mathrm{mg} \mathrm{Cu} ; 1,25 \mathrm{mg} \mathrm{I} ; 0,30 \mathrm{mg}$ Se. *, Calculated value

Table 2- Chemical composition, oleuropein and total phenol contents of olive leaf

\begin{tabular}{lr}
\hline Analyzed values & $\left(\mathrm{g} \mathrm{kg}^{-1}\right)$ \\
\hline Dry matter & 952.60 \\
Crude protein & 91.90 \\
Ether extract & 72.80 \\
Crude ash & 52.40 \\
Crude fiber & 170.21 \\
\hline Oleuropein & 25.10 \\
Total phenol (mg GAE g & $-1)$ \\
\hline
\end{tabular}

Tarım Bilimleri Dergisi - Journal of Agricultural Sciences 25 (2019) 467-473 
$L^{*}, a^{*}, b^{*}$ values (Kim et al 2007). The instrument was calibrated with standard white measuring plate before measurements. The $\mathrm{pH}_{24}$ value of the meat samples at 3 different locations was determined using a pH meter (Hanna Instruments HI 8314) and measured using a direct electrode by thrusting the probe into the incised breast and probe was cleaned in each measurement.

\subsection{Statistical analysis}

All experimental data analyzed using general linear model procedure in SPSS 16.0 package program. In addition, the effect of treatment (oleuropein levels) the MDA contents of samples was determined by regression analysis by defining orthogonal polynomial contrast as linear and quadratic. Differences between the treatment groups were assessed according to the Duncan's Multiple Range test and differences were considered significant at $\mathrm{P}<0.05$ (SPSS 2007).

\section{Results and Discussion}

At the completion of the study, performance parameters did not differ significantly $(\mathrm{P}>0.05)$ among groups (data presented in thesis), indicating that the incorporation of olive leaves to the diets had no adverse influence on the growth rate of broilers (Yavaş 2013).

\subsection{Lipid oxidation on breast meat}

The effect of dietary oleuropein supplementation and storage time on breast meat lipid oxidation was presented in Table 3 and lipid oxidation alteration depending on the storage time was presented in Figure 1. As shown in Table 3, extension of the storage time significantly increased the levels of TBA of breast meat $(\mathrm{P}<0.05)$. Moreover, results showed that dietary oleuropein supplementation at level of $250 \mathrm{mg} \mathrm{kg}^{-1}$ was significantly decreased lipid oxidation on breast meat compared with other groups $(\mathrm{P}<0.05)$.

Our results supported by the findings of studies on Japanese quails (Sarıca \& Toptas 2014) mentioned that 150 and $200 \mathrm{mg} \mathrm{kg}^{-1}$ oleuropein

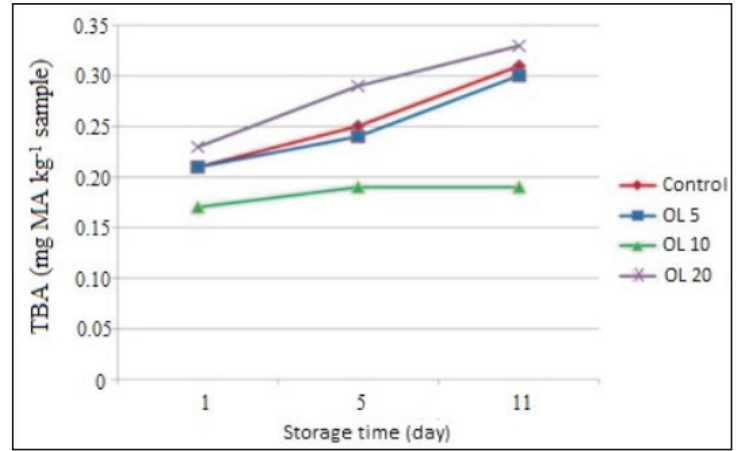

Figure 1- The alteration of TBA value on breast meat samples in experimental groups depends on storage time

Table 3- Effect of treatment and storage time on breast meat lipid oxidation (TBA, mg MDA kg-1 sample)

\begin{tabular}{llc}
\hline \multicolumn{1}{c}{ Sources of variation } & $\begin{array}{c}\text { TBA } \\
\text { (mg MDA kg-1 } \\
\text { sample) }\end{array}$ \\
\hline Treatments & Control & $0.26^{\mathrm{b}}$ \\
& OLE125 & $0.25^{\mathrm{b}}$ \\
& OLE250 & $0.19^{\mathrm{a}}$ \\
& OLE500 & $0.28^{\mathrm{b}}$ \\
& SEM & 0.01 \\
& P & $<0.001$ \\
& Linear & 0.830 \\
& Quadratic & $<0.001$ \\
\hline Storage time, day & 1. & $0.21^{\mathrm{a}}$ \\
& 5. & $0.24^{\mathrm{b}}$ \\
& 11. & $0.28^{\mathrm{c}}$ \\
& SEM & 0.01 \\
Storage Time (ST) & & $<0.001$ \\
\hline T x ST & & \\
\hline Treatment (T) & & $<0.001$ \\
\hline
\end{tabular}

a-c, means within a column with different superscripts are significantly different $(\mathrm{P}<0.05)$; SEM, standard error of means

supplementation on quail diets were effective in delaying lipid oxidation. Similarly, olive leaf supplementation studies on turkeys (Govaris et al 
2010; Botsoglou et al 2010a; Botsoglou et al 2010b) observing that $10 \mathrm{~g} \mathrm{~kg}^{-1}$ olive leaf supplementation on turkey diets was decreased lipid oxidation on breast meat which was stored for 12 days at +4 ${ }^{\circ} \mathrm{C}$ compared to control and summarized that 10 $\mathrm{g} \mathrm{kg}^{-1}$ olive leaf supplementation more effective to prevent lipid oxidation than $10 \mathrm{~g} \mathrm{~kg}^{-1}$ rosemary and $150 \mathrm{mg} \mathrm{kg}^{-1} \alpha$-tocopherol acetate (Govaris et al 2010) and $10 \mathrm{~g} \mathrm{~kg}^{-1}$ thyme (Botsoglou et al 2010b) supplementation respectively. Study on broilers (Marangoni et al 2017) also reported that $5 \mathrm{~g} \mathrm{~kg}^{-1}$ olive leaf supplementation has antioxidant effect on chicken meat during the frozen storage. But these studies not mentioned olive leaf's oleuropein levels. Other in vivo study on laying hens (Aktaş 2012) also reported antioxidant effect of olive leaf extract. In addition to in vivo studies, studies conducted on in vitro also reported antioxidant effect of olive leaf or its phenolic substances (Briante et al 2002; Lee et al 2009; Kiritsakis et al 2010). The antioxidant effect of oleuropein has been reported in studies that it inhibits the formation of free radicals by binding with metal ions such as iron and copper and under favour of this bond suppresses the activities of many inflammatory enzymes such as lipoxygenase (Andrikopoulos et al 2002; Visioli et al 2002; Botsoglou et al 2010a). Studies also have shown that olive leaf has 15 antioxidant substances besides oleuropein such as hydroxytriosol, luteolin7-glucoside, verbascoside, tirosol, vanillic acid (Benavente-Garcia et al 2000; Silva et al 2006). Our result of antioxidant effect of oleuropein is consistent with the reported in the literature. However, OLE500 dietary group in our study did not decrease the TBA value in breast meat sample compared to the control group, on the contrary increased as a numerally, in other words its preventive effect on lipid oxidation was not detected. In a study conducted in in vitro conditions with turmeric extract (Saefudin et al 2014), reported that the use of turmeric extract in high levels causes prooxidant properties instead of antioxidant activity. It is known that polyphenol compounds can display both antioxidant and prooxidant effects (Decker 1997) depending on several factors (chelating potential, solubility, bioavailability and stability in tissues). In this respect $250 \mathrm{mg} \mathrm{kg}^{-1}$ oleuropein leaf supplementation to diet showed the expected antioxidant effect but highest level of supplementation showed prooxidant effect related to usage level.

\subsection{Breast meat color and $\mathrm{pH}_{24}$}

The effect of dietary oleuropein supplementation on 24 hours stored at $4{ }^{\circ} \mathrm{C}$ breast meat color and $\mathrm{pH}_{24}$ were presented in Table 4. As shown in Table 4 , while there was no difference in breast meat lightness, yellowness and $\mathrm{pH}_{24}$ among the treatments $(\mathrm{P}>0.05)$ dietary oleuropein supplementation at different level significantly increased redness value compared to the control group $(\mathrm{P}<0.05)$.

Table 4- Effect of treatment on breast meat color and $\mathrm{pH}_{24}$ value

\begin{tabular}{lllll}
\hline Treatments & $L^{*}$ & $a^{*}$ & $b^{*}$ & $\mathrm{pH}_{24}$ \\
\hline Control & 48.85 & $3.19^{\mathrm{a}}$ & 5.16 & 6.15 \\
OLE125 & 50.67 & $5.67^{\mathrm{b}}$ & 5.47 & 6.11 \\
OLE250 & 51.43 & $6.52^{\mathrm{b}}$ & 5.62 & 6.10 \\
OLE500 & 49.33 & $7.83^{\mathrm{b}}$ & 5.66 & 6.19 \\
SEM & 0.874 & 0.774 & 0.619 & 0.054 \\
P & 0.156 & 0.001 & 0.937 & 0.600 \\
Linear & 0.575 & 0.000 & 0.550 & 0.601 \\
Quadratic & 0.031 & 0.459 & 0.829 & 0.232 \\
\hline
\end{tabular}

$\mathrm{L}^{*}$, lightness; $\mathrm{a}^{*}$, redness; $\mathrm{b}^{*}$, yellowness; ${ }^{\mathrm{a}-\mathrm{b}}$, means within a column with different superscripts are significantly different $(\mathrm{P}<0.05)$; SEM, standard error of means

Our results supported by the findings of study (Marangoni et al 2017) observing that olive leaf supplementation to broiler feed has no effect on $\mathrm{L}^{*}$ and $b^{*}$ values of breast meat but were contrast to findings of $\mathrm{a}^{*}$ value of breast meat and $\mathrm{pH}$. In that study, while olive leaf supplementation has no effect on $\mathrm{a}^{*}$ value, it decreased $\mathrm{pH}$ of the meat during long storage condition (60 days). Studies with different phytobiotics on broiler breast meat color and $\mathrm{pH}$ (Hong et al 2012; Kirkpinar et al 2014; Cho et al 2014; Li et al 2015) reported that increase or decrease in meat color might be related to type and rations of carotenoids found in phytobiotic structures, management, breeding type, carcass weight and pH. Olive leaf's carotenoid amount was reported by 
Cayan \& Erener (2015) as $2 \mathrm{mg} \beta$-carotene and $8 \mathrm{mg}$ lutein $100 \mathrm{~g}^{-1}$ olive leaf in literature and olive leaf supplementation at any level on layer diet increased yolk yellowness in that study. In our study, amount of carotenoid in olive leaf was not determined and increases in $\mathrm{a}^{*}$ value may be related to amount and type of carotenoid in olive leaf.

\section{Conclusions}

As a result, $250 \mathrm{mg} \mathrm{kg}^{-1}$ oleuropein supplementation to broiler diets, decreased lipid oxidation by decreasing TBA value of breast meat sample and it is possible to say that olive leaf demonstrated antioxidant activity linked with oleuropein supplementation level and it can be used at level of $250 \mathrm{mg} \mathrm{kg}^{-1}$ as phytobiotic antioxidant in broiler diets.

\section{Acknowledgements}

This work is a part of the first author's master thesis. The thesis did not include data obtained from this study. This study was supported by Ege University Scientific Research Projects Coordination Unit (Project number 12-ZRF-019).

\section{References}

Aktaş B (2012). The effects of different plant extracts supplementation to egg layers feeds enriched with omega-3 fatty acids on egg efficiency, quality, lipid peroxidation and antioxidant capacity. PhD, Ege University Graduate School of Natural and Applied Sciences (Published), İzmir

Andrikopoulos N K, Kaliora A C, Assimopoulou A N \& Papageorgiou V P (2002). Inhibitory activity of minor polyphenolic and nonpolyphenolic constituents of olive oil against in vitro low-density lipoprotein oxidation. Journal of Medicinal Food 5(1): 1-7

Basmacıoğlu-Malayoğlu H \& Aktaş B (2011). Zeytinyağ işleme yan ürünlerinden zeytin yaprağı ile zeytin karasuyunun antimikrobiyal ve antioksidan etkileri. Hayvansal Üretim 52(1): 49-58

Benavente-Garcia O, Castillo J, Lorente J, Ortuno A \& Del Rio J A (2000). Antioxidant activity of phenolics extracted from Olea europea L. leaves. Food Chemistry 68(4): 457-462
Bisignano G, Tomaino A, Cascio R L, Crisafi G, Uccella $\mathrm{N} \&$ Saija A (1999). On the in vitro antimicrobial activity of oleuropein and hydroxytyrosol. Journal of Pharmacy and Pharmacology 51(8): 971-974

Botsoglou E, Govaris A, Christaki E \& Botsoglou N (2010a). Effect of dietary olive leaves and/or $\alpha$-tocopheryl acetate supplementation on microbial growth and lipid oxidation of turkey breast fillets during refrigerated storage. Food Chemistry 121(1): $17-22$

Botsoglou E, Govaris A, Moulas A \& Botsoglou N (2010b). Oxidative stability and microbial growth of turkey breast fillets during refrigerated storage as influenced by feed supplementation with olive leaves, oregano and/or $\alpha$-tocopheryl acetate. British Poultry Science 51(6): 760-768

Briante R, Patumi M, Terenziani S, Bismuto E, Febbaio F \& Nucci R (2002). Olea europaea L. leaf extract and derivatives: Antioxidant properties. Journal of Agriculture Food Chemistry 50(17): 4934-4940

Cayan H \& Erener G (2015). Effect of olive leaf (Olea europaea) powder on laying hens performance, Egg quality and Egg yolk cholesterol levels. Asian Australasian Journal Animal Science 28(4): 538-543

Cho J H, Kim H J \& Kim I H (2014). Effects of phytogenic feed additive on growth performance, digestibility, blood metabolites, intestinal microbiota, meat color and relative organ weight after oral challenge with Clostridium perfringens in broilers. Livestock Science 160: $82-88$

Decker E A (1997). Phenolics: Prooxidants or antioxidants? Nutrition Reviews 55(11): 396-407

Govaris A, Botsoglou E, Moulas A \& Botsoglou N (2010). Effect of dietary olive leaves and rosemary on microbial growth and lipid oxidation of Turkey breast during refrigerated storage, South African Journal of Animal Science 40(2): 145-155

Hong J C, Steiner T, Aufy A \& Lien T F (2012). Effects of supplemental essential oil on growth performance, lipid metabolites and immunity, intestinal characteristics, microbiota and carcase traits in broilers. Livestock Science 144(3): 253-262

Kim E S, Liang Y R, Jin J, Sun Q F, Lu J L, Du Y Y \& Lin C (2007). Impact of heating on chemical compositions of green tea liquor. Food Chemistry 103(4): 1263-1267

Kiritsakis K, Kontominas M G, Kontogiorgis C, LitinaHadjipavlou D, Moustakas A \& Kiritsakis A (2010). 
Composition and antioxidant activity of olive leaf extracts from Greek olive cultivars. Journal of American Oil Chemists'Society 87(4): 369-376

Kirkpinar F, Ünlü H B, Serdaroğlu M \& Turp G Y (2014). Effects of dietary oregano and garlic essential oils on carcass characteristics, meat composition, colour, $\mathrm{pH}$ and sensory quality of broiler meat. British Poultry Science 55(2): 157-166

Lee O H \& Lee B Y (2010). Antioxidant and antimicrobial activities of individual and combined phenolics in Olea europaea leaf extract. Bioresource Technology 101(10): 3751-3754

Lee O H, Lee B Y, Lee J, Lee H B, Son J, Park C S, Shetty K \& Kim Y C (2009). Assessment of phenolicsenriched extract and fractions of olive leaves and their antioxidant activities. Bioresource Technology 100(23): 6107-6113

Li H L, Zhao P Y, Lei Y, Hossain M M \& Kim I H (2015). Phytoncide, phytogenic feed additive as an alternative to conventional antibiotics, improved growth performance and decreased excreta gas emission without adverse effect on meat quality in broiler chickens. Livestock Science 181: 1-6

Loetscher Y, Kreuzer M \& Messikommer R E (2013). Oxidative stability of the meat of broilers supplemented with rosemary leaves, rosehip fruits, chokeberry pomace, and entire nettle, and effects on performance and meat quality. Poultry Science 92(11): 2938-2948

Marangoni C, Cichoski A J \& Barin J S (2017). Effect of olive leaves on the quality of chicken meat during frozen storage. International Food Research Journal 24(1): 164-172

Markin D, Duek L \& Berdicevsky I (2003). In vitro antimicrobial activity of olive leaves. Mycoses 46(34): $132-136$

Saefudin F, Syarif F \& Chairul C (2014). Antioxidant potential and proliferative activity of Curcuma Zedoaria Rosc. extract on Hela Cells. Widyariset 17(3): 381-390

Sarica S \& Toptas S (2014). Effects of dietary oleuropein supplementation on growth performance, serum lipid concentrations and lipid oxidation of Japanese quails. Journal of Animal Physiology and Animal Nutrition 98(6): 1176-1186

Silva S, Gomes L, Leitao F, Coelho A V \& Vilas-Boas L (2006). Phenolic compounds and antioxidant activity of Olea europea L. fruits and leaves. Food Science and Technology International 12(5): 385-396

SPSS (2007). SPSS for windows, release 13.00 SPSS Inc, Chicago, Illinois, USA

Visioli F, Poli A \& Galli C (2002). Antioxidant and other biological activities of phenols from olives and olive oil. Medicinal Research Reviews 22(1): 65-75

Witte V C, Krause G F \& Bailey M E (1970). A new extraction method for determining 2-thiobarbituric acid values of pork and beef during storage. Journal of Food Science 35(5): 582-585

Yavaş İ (2013). The effects of olive leaf supplementation to broiler diets on performance, some blood parameters and intestinal microflora, Master Thesis, Ege University Graduate School of Natural and Applied Sciences (Published), İzmir 